DOI https://doi.org/10.30525/978-9934-26-004-9-90

\title{
СОЦІАЛЬНИЙ АСПЕКТ ДРАМАТУРГІЇ ЦИРКОВИХ ВИДОВИЩ ЯК ВАЖЛИВА СКЛАДОВА В МОДЕЛЮВАННІ КОНЦЕПЦИЙ ЕЛІТАРНОЇ ТА МАСОВОЇ КУЛЬТУР
}

\author{
Мельник М. М. \\ кандидат мистецтвознавства, доцент, \\ доиент кафедри режисури естради та масових свят \\ Київського національного університету культури і мистецтвв \\ м. Київ, Украӥна
}

Будучи багатофункціональною структурою, циркове мистецтво завжди конструює своєрідне культурне середовище за власними законами, соціальною активністю й суміщенням в собі реалій сучасності та історичних традицій. Становлення і розвиток мистецтва цирку тісно взаємопов'язане з розвитком суспільства й цивілізації в цілому. Етикосоціальний аспект циркового видовища спрямований на гуманізацію суспільства, його морально-етичне виховання та формування. У послідовному аналізі концептуального задуму та новітнього підходу до створення й проведення циркових видовищ як мистецької форми молодіжної культури, чітко прослідковується синтез мистецтв та впровадження сучасних прийомів в сучасну драматургію.

Циркове мистецтво багатогранне. За всю історію існування утворилось безліч форм, стилів, жанрів, іноді набуваючи кардинальних відмінностей за змістом і формою. Створювались номери елементарні, прості, розраховані на невибагливого глядача, однак у процесі вдосконалення номери стали складні в професійному та технічному виконанні, в основі яких полягали інноваційні досягнення сучасної техніки.

Протягом століть мистецтво цирку міцно увійшло в суспільну свідомість та у повсякденне життя кожного народу. Це - галузь видовищ, яскравих шоу, яке у практичному та теоретичному досвіді набуло своїх індивідуальних рис художньо-естетичної місії. «Цирк говорить 3 реципієнтом мовою своїх образів, виявляючи істотний характер явищ багатогранного i багатобарвного світу, передусім у контексті гармонізації цілісної особистості. Специфіку циркового мистецтва визначає пріоритет емоційної складової образності його природи, яка викликає сплеск емоцій і почуттів реципієнта: вплив обумовлює властива 
цирку іманентна здатність збуджувати почуття естетичної насолоди. Циркове мистецтво відбиває “урочистість здібностей” у злитті з красою тіла циркового артиста, іншими словами, естетично повторно створює або наново відкриває цілісну людину 3 погляду законів краси, збагачуючи її природу і виразно прославляючи» [1, с. 19].

Мистецтво цирку активно розвивається, з кожним роком культурне життя країни збагачується різноманітними цирковими видовищами та атракціонами, поширюється гастрольна діяльність зарубіжних циркових колективів, що безперечно сприяє культурному й духовному об'єднанню українського народу. Циркове мистецтво займає особливе місце в просторі соціокультурної діяльності, вирізняючись високим ступенем значущості для суспільства, окремої особистості у сфері міжнародних відносин. «На кожному етапі свого генезису циркова вистава стояла разом з цілим спектром драматургічних проблем: примітивність сюжетів балаганнх видовищ та гумору; вирішення в цирковій виставі «Глобальних» питань людства через призму гумору; пошуки нових рішень для зацікавлення глядача та, іноді не зовсім вдале, поєднання театру й цирку, що врешті-решт призвело до цілковитої театралізації циркової вистави. I, зрештою, до прагнення сучасного цирку щодо створення цілісної, стилістично виваженої вистави 3 чіткою драматургією. Підкреслюється, що «репертуарне питання було особливо актуальним в усі часи. Нині воно $є$ першочерговим, а професія драматурга циркового видовища лише набуває свого особливого значення» [2, с. 25].

Сучасна циркова програма існує за всіма загальними закономірностями драматургії, синтезує надбання карнавально-сміхової культури та підпорядковує їх конкретному сценарному задуму. Саме в цьому контексті, говорячи про сучасну постановку циркової програми, варто зазначити, що це - поліфункціональне явище соціальнокультурологічного змісту, яке відображає дійсність у постійному пошуку нових напрямів свого розвитку.

Отже, нині циркове мистецтво органічно синтезує надбання попередніх етапів свого розвитку, однак спрямовує їх у сучасний ракурс. Карнавальні форми стали притаманні параду-алє, визначилась спільна драматургічна конфліктна основа та композиція обох видовищ.

Мистецтво цирку як в минулому, так і в сьогоденні швидко реагує на конкретні події, факти, явища, які відбуваються у житті суспільства. Змінюються погляди, настрої, умови, відповідно змінюється й ідейнотематична спрямованість циркових видовищ. Такі зміни відразу 
знаходять пристосування для їх втілення на манежі, набуваючи специфічної художньої форми.

«Сьогодення циркового мистецтва у порівнянні 3 часами давнини зазнало значних перетворень в організаційній складовій. За останні сто років 3'являються та функціонують у цирковій галузі продюсерські агенції, приватні імпресаріо, залучаються власні, спонсорські кошти, використовується фандрейзинг. Протягом десятиліття видовищна природа циркового мистецтва постійно змінюється, використовуючи багатий досвід і визнані досягнення театрального, хореографічного, музичного та інших видів мистецтва. Створюються нові постановки, трюкові ноу-хау та інші авторські розробки українських режисерів та артистів, які постійно отримують визнання в усьому світі» [3, с. 242].

Циркове мистецтво - це мистецький продукт, який естетично реалізує власний знаково-символічний простір, що має свій соціотропний й соціокультурний побут. Його природа - безперервна історична еволюція, де поступово синтезуються художні форми театру, естради, образотворчого мистецтва, музики, кіно, національних традицій тощо. Відношення між мистецтвами мали характер взаємного обміну: мистецтва впливали на розвиток цирку i, навпаки, циркове мистецтво впливало на суміжні види мистецтв.

Варто зауважити, що сучасне циркове мистецтво орієнтується на естетичні цінності європейської культури. Свропейські циркові школи, студії, їх зразки впливають на постановки циркових видовищ в Україні. Сьогодні український цирк $є$ унікальним феноменом 3 репертуаром, в якому представлені номери різних культур. Наприклад, на розвиток вітчизняного цирку має великий вплив Cirque du Soleil (Цирк дю Солей) 3 багатонаціональним репертуаром. Тому, можна стверджувати, що українське циркове мистецтво впевнено розвивається та істотно змінюється завдяки міжнародним культурно-мистецьким відносинам, однак при цьому зберігаючи свою національну культуру.

\section{Література:}

1. Баринов В. А. Художественно-образная структура циркового искусства : монография. Москва : МГУКИ, 2005. 192 с.

2. Вяткин Б. Один из моих дней // Искусство клоунады. Москва : 1988. C. 238.

3. Мельник І.П. Специфіка діяльності аматорських колективів у контексті українського циркового мистецтва / Молодий вчений. - 2018. № 4(1). C. 240-243. Режим доступу: http://nbuv.gov.ua/UJRN/ molv_2018_4(1)_57. (Дата звернення: 22.11.2020.) 